\title{
Annual abundance of salps and doliolids (Tunicata) around Gorgona Island (Colombian Pacific), and their importance as potential food for green sea turtles
}

\author{
Laura Sampson ${ }^{1 *} \&$ Alan Giraldo ${ }^{1,2}$ \\ 1. Departamento de Biología, Facultad de Ciencias Naturales y Exactas, Universidad del Valle, Cali, Colombia; \\ lausamps@gmail.com; ecologia@univalle.edu.co \\ 2. Departamento de Biología, Facultad de Ciencias Naturales y Exactas, Universidad del Valle, Cali, Colombia; \\ oceanografí@@univalle.edu.co
}

Recibido 18-X-2013. Corregido 20-XI-2013. Aceptado 19-XII-2013.

\begin{abstract}
Gorgona National Park protects fertile waters that support large vertebrates, including green sea turtles (Chelonia mydas), and for them, gelatinous zooplankton constitute a food resource that can be found year-round in Gorgona Island's coastal waters. This study was carried out to determine the abundance of salps and doliolids around Gorgona Island over a year, and to determine whether this is a resource that could be used reliably year-round by green turtles and other large plankton-feeding predators. The monthly abundance of salps and doliolids at eight coastal stations around Gorgona Island (Colombian Pacific) was determined between September 2005 and August 2006. Oblique tows were carried out from 50m to the surface, total zooplankton biomass was measured and the number of salps and doliolids per tow, and frequency of occurrence per station and month were determined. Superficial and bottom sea temperature, superficial and bottom salinity, and chlorophyll- $a$ concentration were recorded at each station. There were tunicate abundance peaks in September 2005 and March 2006. The high abundances in March were probably due to a cold water intrusion into the study area, which resulted in colder saltier water and a shallower thermocline. Tunicates were probably advected to the area by currents from the southwest and aggregated due to the underwater topography. In September, the influence of continental river discharge as well as inputs from rainfall over the island could have provided increased nutrients and resulted in higher abundances. The large filter-feeding vertebrates that feed on tunicates include green sea turtle juveniles, which use coastal waters of Gorgona Island as feeding grounds, as part of their migration route in the Eastern Tropical Pacific. These turtles could be using tunicates opportunistically, as a sporadic resource that is available at certain times of the year. Rev. Biol. Trop. 62 (Suppl. 1): 149-159. Epub 2014 February 01.
\end{abstract}

Key words: Chelonia mydas, tunicates, Salpidae, Doliolidae, Gorgona Island, opportunistic trophic behaviour, advection.

Gorgona National Park protects the most developed reef on the Eastern Tropical Pacific, and coastal waters around the island provide resources for a variety of plant and animal life (Zapata, 2001; Giraldo \& Valencia, 2012). Several large plankton-feeding vertebrates such as manta rays, devil rays and whale sharks feed in Gorgona Island's coastal waters (Acero \& Franke, 2001). The oceanographic conditions of the island provide a setting that fosters the presence of a diverse zooplankton community that includes mostly copepods, decapods and polychaetes. Gelatinous zooplankton, including pelagic tunicates (salps and doliolids) can be found in coastal waters year-round (Soto, Sánchez \& Fernández, 2001).

Pelagic tunicates are large transparent animals that can measure up to $25 \mathrm{~cm}$ (Lavaniegos \& Ohman, 2003). They are mainly herbivorous filter feeders that feed on diatoms, dinoflagellates, radiolarians and foraminiferans, among others (Alldredge \& Madin, 1982; Kremer, 2002). Their life cycle alternates between sexual solitary structures and asexual 
colonies that reproduce by gemmation, and can produce hundreds of thousands of individuals. This allows rapid increases in population numbers (Graham, Pagès \& Hamner, 2001). Sudden increases in tunicate populations possibly linked to increases in food abundance have been observed in previous studies, with densities of up to $7000 \mathrm{ind} / \mathrm{m}^{3}$ being recorded (Alldredge \& Madin, 1982).

Several large predators consume pelagic tunicates, such as sea turtles, tuna, cod, ocean sunfish, flying fish, jellyfish, siphonophores, ctenophores, and heteropod molluscs (Alldredge \& Madin, 1982; Dewar et al., 2010; Hays, Farquhar, Luschi, Teo \& Thys, 2009; Madin, Kremer \& Hacker, 1996; Montenegro, Bernal-González \& Martínez-Guerrero, 1984; Potter, Galuardi \& Howell, 2011). Leatherback turtles Dermochelys coriacea are known to feed mainly on gelatinous organisms such as jellyfish, salps and pyrosomes, and the olive ridley turtle Lepidochelys olivacea occasionally feeds on salps (Hays et al., 2009, Montenegro et al., 1984). The green turtle Chelonia mydas has a mainly herbivorous diet, but in the eastern Pacific, where seagrass pastures are not available, green sea turtles also include animal protein in their diet (Bjorndal, 1985; Amorocho \& Reina, 2007). Gorgona Island is the only known feeding ground for juvenile green turtles in the Colombian Pacific, and in this area pelagic tunicates can make up a large component of their diet (66\% dry weight, Amorocho \& Reina, 2007).

Of the known predators of pelagic tunicates present around Gorgona Island, the green sea turtle is the only species that is the focus of a Management Plan for Gorgona National Park (Acevedo-Bueno et al., 2004), and determining the availability of this resource for the turtles would be beneficial for future management actions. The objective of this study was therefore to determine the abundance of salps and doliolids in coastal waters of Gorgona Island over the course of a year, and to determine whether this is a resource that could be used reliably year-round by green turtles and other large plankton-feeding predators.

\section{MATERIALS AND METHODS}

Study area: Gorgona National Park is located off the Pacific coast of Colombia; it encompasses a $6033 \mathrm{~km}^{2}$ marine area that includes Gorgona Island $\left(13.3 \mathrm{~km}^{2}\right)$. It is located within the Inter-Tropical Convergence Zone, which has a marked influence on local winds, temperature and precipitation (RodríguezRubio, Schneider \& Abarca del Río, 2003). The coastal oceanography of Gorgona Island is influenced by cyclonic gyres generated by the trade winds. Two contrasting oceanographic periods have been detected for the area: a warm, low-salinity period with a deep thermocline $(47 \mathrm{~m})$ from May to December (rainy season), and a cold, high-salinity period with a shallow thermocline $(7.5 \mathrm{~m})$ from January to April (dry season; Giraldo, Rodríguez-Rubio \& Zapata, 2008; Giraldo, Valencia \& Ramírez, 2011). Circulation patterns also show two contrasting periods: one during the northern hemisphere summer, with currents moving towards the south-west, and another one during the northern hemisphere winter, with currents moving towards the north-east (Rodríguez-Rubio et al., 2003; Giraldo et al., 2008).

The fringing coral reefs on the eastern side of the island provide habitat and resources for a variety of organisms, including fish, echinoderms, polychaetes, mollusks, crustaceans, bryozoans, hydroids, sponges and algae, among others (Barrios-Suárez \& López Victoria, 2001; Acevedo-Bueno, Beltrán-León \& CaicedoTulante, 2004; Zapata, Rodríguez-Ramírez, Caro-Zambrano \& Garzón-Ferreira, 2010). The pelagic zone also offers food resources, with 136 species of phytoplankton $(75 \%$ diatoms and 23\% dinoflagellates in October; $69 \%$ diatoms and 30\% dinoflagellates in March), and 96 zooplankton families having been reported (Soto et al. 2001; Giraldo et al., 2011; Giraldo, Valencia, Acevedo \& Rivera, 2013).

Gorgona Island's coastal zone does not include seagrasses or mangroves, which are food resources used by $C$. mydas in other parts of the world (Bjorndal, 1985; AcevedoBueno et al., 2004). There are eighty-five 
algae species (17 Chlorophyta, 15 Phaeophyta, and 54 Rhodophyta) with a predominance of encrusting red algae (Bula-Meyer, 1995), which is noticeably lower than the number of species reported for Baja California (998 sp.), the Galápagos Islands (316 sp.), and Hawaii (400 sp.), places where C. mydas has been reported to feed mainly on algae (LópezMendilaharsu, Gardner, Riosmena-Rodríguez \& Seminoff, 2008, Arthur \& Balazs, 2008, Carrión-Cortez, Zárate \& Seminoff, 2010; Fernández-García, Riosmena-Rodríguez, Wysor, Tejada, \& Cortés, 2011).

Field sampling, laboratory work and data analysis: Oblique diurnal tows were carried out once a month from $50 \mathrm{~m}$ to the surface, at eight coastal stations (see Fig. 3 for station numbers and locations), from September 2005 to August 2006, using a 30cm mouth diameter bongo net with $250 \mu \mathrm{m}$ mesh size. A flowmeter (General Oceanics) was placed in the center of the net to determine filtered volume $\left(11.09 \mathrm{~m}^{3}\right.$ on average were filtered during each tow). All samples were preserved in 10\% formalin. Temperature and salinity were recorded at the surface and at the bottom (or at $50 \mathrm{~m}$, depending on depth at each station), in September, November and December 2005, and March and June 2006, using a CTD (Seabird-19). Superficial chlorophyll- $a$ concentrations were recorded from February to August 2006, using an AquaFluor ${ }^{\circledR}$ handheld fluorometer (Turner Designs). The thermocline was determined as the depth where the temperature was $20^{\circ} \mathrm{C}$.

Separation and quantification of samples was done at the Animal Ecology Laboratory of the Universidad del Valle. Total zooplankton biomass in wet weight was recorded and the total number of organisms counted (Giraldo et al., 2011). A subsample ( $1 / 2$ or $1 / 4)$ was taken, and all tunicates (salps and doliolids) were separated and counted using a stereoscope. Unfortunately, organisms could not be identified to species due to sample deterioration caused by prolonged storage. Tunicate abundances were classified according to the following categories: 1) $1-3 \mathrm{ind} / \mathrm{m}^{3}, 2$ )
4-17 ind $\left./ \mathrm{m}^{3}, 3\right) 18-80 \mathrm{ind} / \mathrm{m}^{3}$, 4) $80-350 \mathrm{ind} /$ $\mathrm{m}^{3}$, and 5) 350-1 $500 \mathrm{ind} / \mathrm{m}^{3}$ (Frontier, 1969; Ménard, Dallot, Thomas \& Braconnot, 1994).

The salp and doliolid frequency of occurrence was calculated for each station as $\mathrm{FO} \%_{\text {station }}=$ (months with salps or doliolids present at each station/total number of stations) $\mathrm{x}$ 100 , and for each month as $\mathrm{FO} \%{ }_{\text {month }}=$ (months with salps or doliolids present each month/ total number of stations) $\mathrm{x} 100$. The number of tunicates (number of salps or doliolids/ $\mathrm{m}^{3}$ ) obtained during each tow was calculated as number of salps or doliolids per tow/total filtered volume in $\mathrm{m}^{3}$. The percentage of tunicates compared to all other zooplankton was calculated as tunicate $\%=$ (number of salps or doliolids $/ \mathrm{m}^{3}$ /total zooplankton in $\mathrm{m}^{3}$ ) x 100 .

Kruskal-Wallis tests, post-hoc non-parametric multiple comparisons and Spearman's correlations were used to compare abundances, salinity, temperature and chlorophyll- $a$ concentrations between stations and months, using Statistica v. 8.0 (StatSoft). ArcMap 10.0 was used to create maps depicting the proportion of tunicates vs. zooplankton at each station.

\section{RESULTS}

Environmental variables: There were annual variations in sea surface temperature (SST), sea bottom temperature (SBT), sea surface salinity (SSS) and sea bottom salinity (SBS) (Kruskal-Wallis, $\mathrm{p}<0.05$ ). SST was more variable in March (range of $23.8-27.5^{\circ} \mathrm{C}$ ) than during the rest of the year (average \pm st. dev, $27.2^{\circ} \mathrm{C} \pm 0.37^{\circ} \mathrm{C}$ ). SSS was variable in September, ranging from 26.2UPS to 30.7UPS, while the rest of the year the average was $30.7 \pm 0.96$. SBT and SBS had no defined pattern, ranging from $15.1{ }^{\circ} \mathrm{C}$ to $27.5^{\circ} \mathrm{C}$ and 28.9 UPS to 34.9UPS, respectively.

Thermocline depths varied during the year (Table 1). In March the thermocline was shallower $(10.6 \mathrm{~m})$ than the rest of the year (average $46.5 \mathrm{~m}$ ). This shallower thermocline was also detected by Giraldo et al. (2013) during March 2011. Chlorophyll $a$ values were also significantly different during the year 
TABLE 1

Sea surface temperature (SST), Sea bottom temperature (SBT), Sea surface salinity (SSS), Sea bottom salinity (SBS), and Thermocline depth from September 2005 to June 2006.

\begin{tabular}{cccccc} 
& SST $\left({ }^{\circ} \mathrm{C}\right)^{*}$ & SBT $\left({ }^{\circ} \mathrm{C}\right)$ & SSS & SBS & Thermocline depth $(\mathrm{m})$ \\
Sep-05 & $27.26 \pm 0.08$ & $24.25 \pm 3.94$ & $29.46 \pm 1.50$ & $32.19 \pm 1.44$ & 47.68 \\
Nov-05 & $26.93 \pm 0.10$ & $22.45 \pm 5.85$ & $29.92 \pm 0.20$ & $32.13 \pm 2.32$ & 39.75 \\
Dec-05 & $26.99 \pm 0.12$ & $23.00 \pm 4.76$ & $30.22 \pm 0.48$ & $32.73 \pm 1.49$ & 47.56 \\
Mar-06 & $26.17 \pm 1.19$ & $18.95 \pm 3.79$ & $31.41 \pm 0.81$ & $34.27 \pm 0.95$ & 10.57 \\
Jun-06 & $27.80 \pm 0.17$ & $25.70 \pm 2.78$ & $31.33 \pm 0.96$ & $32.89 \pm 0.86$ & 50.91 \\
\hline
\end{tabular}

$*=$ average \pm standard deviation.

(Kruskal-Wallis, $\mathrm{p}<0.05$ ), with higher values in April (Table 2).

Tunicate annual abundances: There was a significant difference in doliolid abundance during the year (Kruskal-Wallis, $\mathrm{p}<0.05$ ), with maximal abundances (categories 3 to 5) in September 2005 (515.4 ind $/ \mathrm{m}^{3}$, Station 1) and March 2006 (1 $085.1 \mathrm{ind} / \mathrm{m}^{3}$, Station 1). The rest of the year there were very few doliolids $\left(<18\right.$ ind $/ \mathrm{m}^{3}$; Fig. 1). In September doliolids comprised $17.2 \%$ of total zooplankton and in March 2006 they made up $23.1 \%$ of total zooplankton (Fig. 3).

Salp abundances were also statistically different during the year (Kruskal-Wallis, $\mathrm{p}<0.05$ ). Maximal abundances (categories 3 to 4) were observed in September 2005 (36.14 ind $/ \mathrm{m}^{3}$, Station 4), February 2006 (90.1ind/ $\mathrm{m}^{3}$, Station 1), and March 2006 (43.9ind $/ \mathrm{m}^{3}$, Station 7), while the rest of the year abundances were $<18 \mathrm{ind} / \mathrm{m}^{3}$ (Fig. 1). Salps made up $1.98 \%$ of total zooplankton in September 2005, $4.27 \%$ in February 2006 and $12.05 \%$ in March 2006 (Fig. 3).

Fig. 2 shows that tunicates were collected at all stations around the island, although they occurred in higher abundances at some locations (salps: stations 1, 10 and 19; doliolids: stations 1, 7, 13, 16, 19 and 22). Although no salps were recorded in May or August 2006 and no doliolids were recorded in February 2006, the frequency of occurrence by month showed that tunicates were available around Gorgona Island year-round.

No differences in tunicate abundances were detected among stations (Kruskal-Wallis, $\mathrm{p}>0.05$ ); however, the highest abundances of

TABLE 2

Monthly chlorophyll-a concentrations, salp and doliolid abundances from September 2005 to August 2006

\begin{tabular}{cccc} 
& Salps $\left(\mathrm{ind} / \mathrm{m}^{3}\right)^{*}$ & Doliolids $\left(\mathrm{ind} / \mathrm{m}^{3}\right)$ & Chlorophyll- $a(\mathrm{mg} / \mathrm{L})$ \\
Sep-05 & $9.60( \pm 12.54)$ & $83.32( \pm 174.84)$ & N.D. \\
Oct-05 & $0.16( \pm 0.24)$ & $1.24( \pm 1.18)$ & N.D. \\
Nov-05 & $1.07( \pm 1.34)$ & $2.10( \pm 2.46)$ & N.D. \\
Dec-05 & $0.02( \pm 0.06)$ & $10.57( \pm 6.50)$ & N.D. \\
Jan-06 & $0.44( \pm 0.73)$ & $1.12( \pm 1.03)$ & N.D. \\
Feb-06 & $19.81( \pm 32.07)$ & 0.00 & $0.310( \pm 0.24)$ \\
Mar-06 & $9.43( \pm 11.90)$ & $164.06( \pm 373.11)$ & $0.442( \pm 0.20)$ \\
Apr-06 & $0.17( \pm 0.25)$ & $1.10( \pm 0.95)$ & $0.653( \pm 0.25)$ \\
May-06 & 0.00 & $0.11( \pm 0.21)$ & $0.301( \pm 0.24)$ \\
Jun-06 & $1.24( \pm 0.92)$ & $2.08( \pm 1.93)$ & $0.320( \pm 0.13)$ \\
Jul-06 & $1.74( \pm 1.49)$ & $1.41( \pm 2.16)$ & $0.132( \pm 0.02)$ \\
Aug-06 & 0.00 & $2.22( \pm 3.25)$ & $0.134( \pm 0.02)$ \\
\hline
\end{tabular}

\footnotetext{
$*=$ average \pm standard deviation.
} 

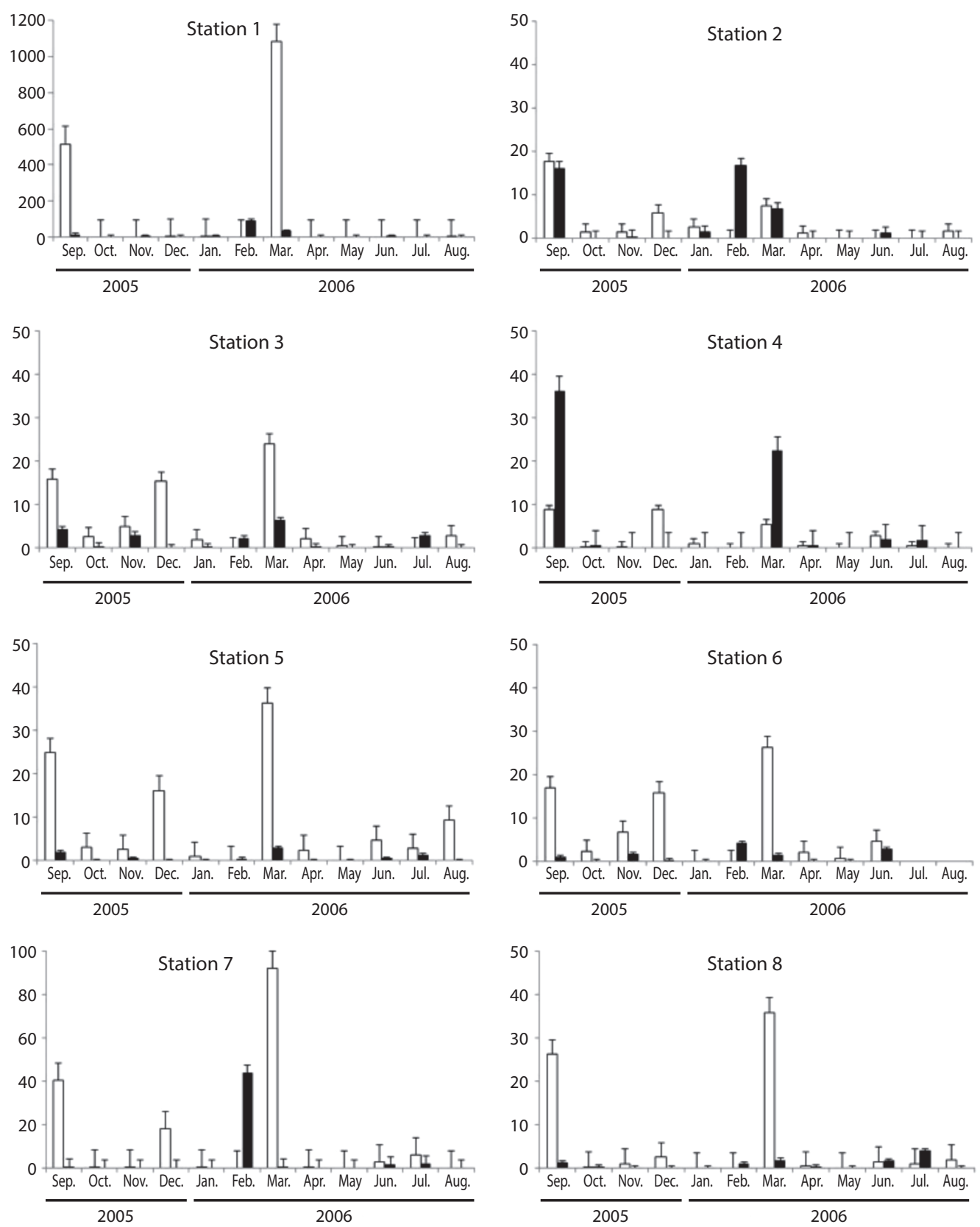

Fig. 1. Salp (black bars) and doliolid (white bars) abundance in ind $/ \mathrm{m}^{3}$ between September 2005 and August 2006, at coastal stations around Gorgona Island. Note: Station 1 is on a different scale due to the high abundance at this station.

salps and doliolids were detected at Station 1. Spearman correlations indicated that in December 2005 doliolid abundances were significantly correlated with SBT $\left(r_{s}=0.85, \mathrm{p}<0.05\right)$, while salps were significantly correlated with SBT in March $2006\left(r_{s}=-0.71, \mathrm{p}<0.05\right)$. In December, SBT was $23^{\circ} \mathrm{C}$ on average, while in March it was $19^{\circ} \mathrm{C}$ on average (Table 2). 

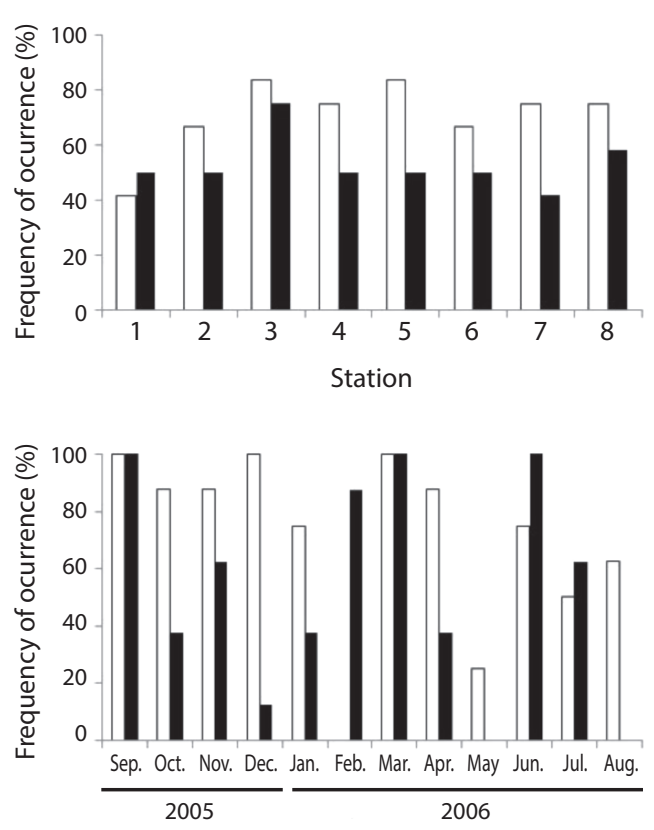

Fig. 2. Salp (black bars) and doliolid (white bars) frequency of occurrence between September 2005 and August 2006 around Gorgona Island.

Salps were significantly correlated with chlorophyll $a$ concentrations in February $\left(r_{s}=0.83, \mathrm{p}<0.05\right)$ and April $2006\left(r_{s}=-0.76\right.$, $\mathrm{p}<0.05)$. April had the highest chlorophyll $a$ concentrations $(0.653 \mathrm{mg} / \mathrm{L})$, while February had an intermediate concentration of 0.310 $\mathrm{mg} / \mathrm{L}$ (Table 2). It seems therefore that salps do not occur in high abundances when chlorophyll $a$ concentrations are high, and that their abundances are higher when chlorophyll $a$ concentration is intermediate.

\section{DISCUSSION}

There was a clear seasonal pattern of tunicate abundance around Gorgona Island in 2005-2006. March 2006 was characterized by a shallower thermocline and very high abundances of salps and doliolids. This is the driest month of the year, part of the dry season that goes from January to April, with higher salinity and lower temperatures (Giraldo et al., 2008; Blanco, 2009). The shallow thermocline is indicative of intrusions of colder water masses that are probably coming from the southwest during the northern hemisphere winter (Rodríguez-Rubio et al., 2003). This is supported by the fact that Station 1, located at the southern tip of the island, had the highest tunicate abundances.

Giraldo et al. (2008) described a change in current patterns in February compared to June; they reported that during February and March there was a stronger influence of the Colombia current, which could be advecting tunicates towards the area. It is possible that this change resulted in the advection of tunicates towards coastal stations. These currents could be responsible for the changes in temperature and salinity observed during the present study. Station 1 is characterized by being shallower (the bottom was encountered 5-16m from the surface). If water masses move towards the island from the southwest and collide against underwater topography at the southern tip of the island, tunicates would get aggregated in this area, explaining the high abundances observed.

In September 2005 high abundances of salps and doliolids were also observed. This month was characterized by warmer temperatures, a deeper thermocline and less saline water, with the highest range in SSS (4.46UPS). High variability in salinity during September was also reported by Giraldo et al. (2008), and could be explained in part by the increased rainfall over Gorgona Island from April to December, and in part by the influence of the continental rivers of the Patía-Sanquianga complex over the study area (Giraldo, 2008; Blanco, 2009). River discharge could bring nutrients to the study area and tunicates could benefit by feeding on small particles and microbes, thereby increasing their numbers (Pagès \& Gili, 1991; Deibel \& Paffenhöfer, 2009).

Graham et al. (2001) stated that there are two kinds of blooms: those due to productivity changes, in which the local abundance of tunicates increases, and those due to currents, in which increases in tunicate numbers are due to passive transport to a given place, such as 

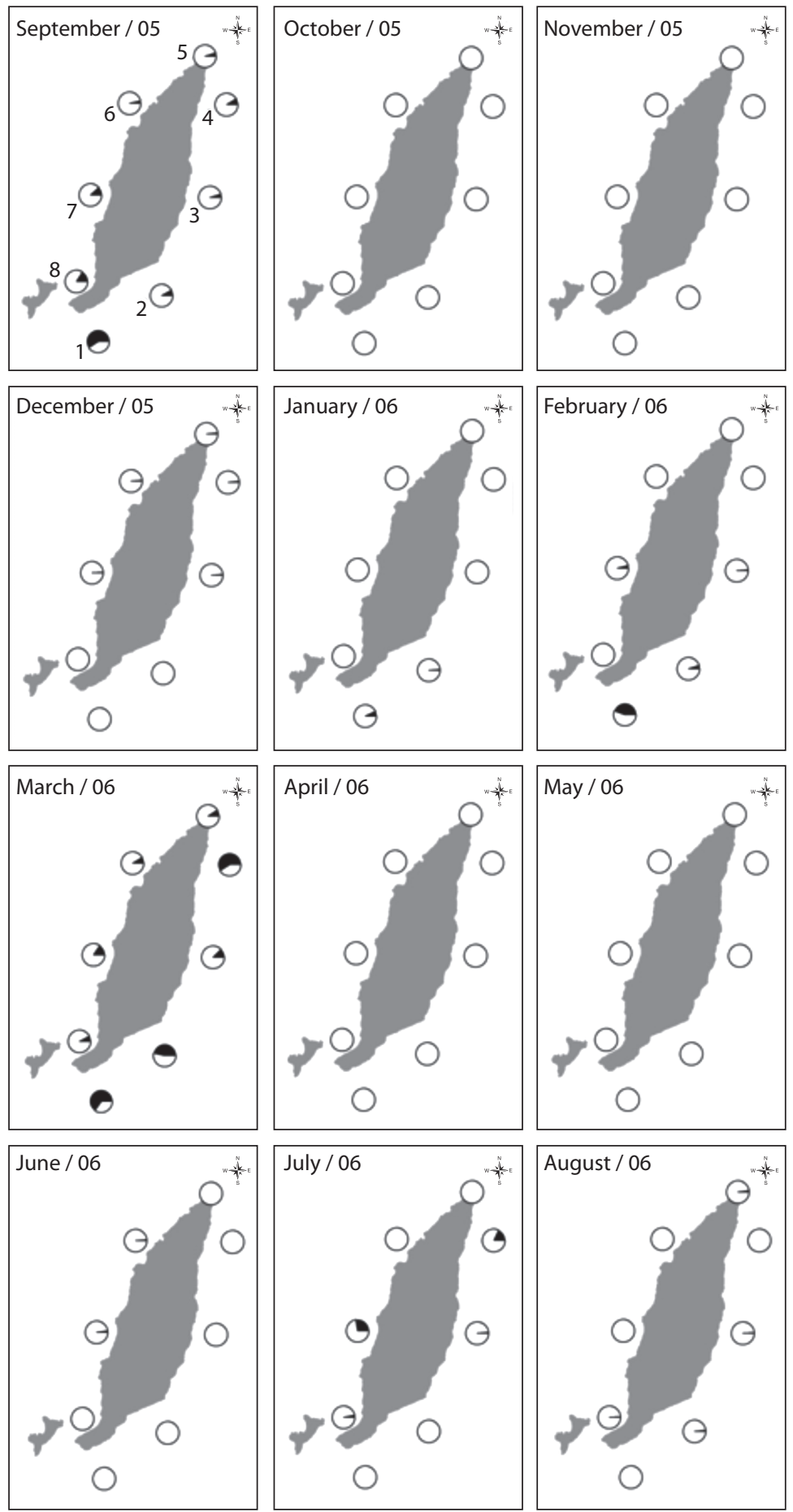

Fig. 3. Proportion of tunicates vs. total zooplankton from September 2005 to August 2006. 
tunicate aggregations that occur near coasts due to transport, and retention by winds and by local hydrology that interact with topography. The high abundances observed were probably not due to upwelling, since for high abundances of zooplankton to be observed, an increase in chlorophyll $a$ in the area would have to be observed first, which was not the case during this study. The population increase that was observed was probably due to an accumulation of individuals, resulting from the interaction of topography and mesoscale currents (Genin, Jaffe, Reef, Richter \& Franks, 2004). The mesoscale advective processes observed in coastal waters of Gorgona Island in 20052006 could be an example of increases in zooplankton biomass due to currents and not upwelling (Pagès \& Gili, 1991).

The lack of an increase in tunicate population size with an increase in chlorophyll $a$ indicates that the maximum abundance recorded for tunicates was not due to an increase in prey abundance. Additionally, Alldredge \& Madin (1982) suggested that no tunicates are usually found during phytoplankton blooms, because tunicates cannot change their filtering velocity according to food availability. If the food concentration is too high, the filters become saturated and the tunicates stop feeding.

Tunicates are important links in the trophic chain, as they are effective filter-feeding predators that can ingest a wide range of particle sizes (Kremer, 2002). They can increase their population numbers in a very short time and consume large amounts of phytoplankton, transferring large amounts of carbon as fecal pellets to the aphotic zone (Deibel \& Paffenhöfer, 2009). They are also consumed by a large number of predators that range in size from siphonophores to tuna and sunfish (Alldredge \& Madin, 1982; Madin et al., 1996; Potter et al., 2011).

Gelatinous organisms are the main prey items in the diet of leatherback sea turtles Dermochelys coriacea, and have also been recorded in the diet of the olive ridley sea turtle Lepidochelys olivacea and the green sea turtle Chelonia mydas (Montenegro-Silva et al., 1984, Amorocho \& Reina, 2007; Hays et al., 2009). Green sea turtles are mainly herbivorous in the Atlantic, consuming seagrasses and algae, whereas in other areas such as the eastern Pacific and Africa they also include animal protein in their diets (Bjorndal, 1985).

Green sea turtle juveniles arrive at Gorgona Island as part of their migratory route in the Eastern Pacific Ocean, and use the island's coastal waters as feeding grounds for an unknown period of time (Alvarado \& Figueroa, 1992; Amorocho \& Reina, 2008). Green sea turtles reach the juvenile phase at around $35 \mathrm{~cm}$ curved carapace length in the Pacific, and this development phase is when the fastest growth occurs in wild sea turtles (Zug, Balazs, Wetherall, Parker \& Murakawa, 2002); it has been hypothesized that a diet rich in protein would allow green turtles to reach their maturation size at a faster rate (Amorocho \& Reina, 2007). The availability of an easily captured prey such as tunicates would therefore be an important resource for green turtles around Gorgona Island. Although tunicates are gelatinous organisms that are $95 \%$ water, sea turtles could take advantage of high-density patches that provide more energy (Alldredge \& Madin, 1982; Genin et al., 2004). It is probable that the diversity and abundance of algae around Gorgona Island is not sufficient to support a completely herbivorous diet for C. mydas, and other food sources, such as tunicates, could potentially be an important source of nutrients.

Tunicates as a food resource seem to occur in high abundances seasonally around Gorgona Island. In other locations high punctual abundances have also been reported, with population numbers being affected by local productivity, currents, topography, and temperature (Graham et al., 2001, Hereu, Lavaniegos, GaxiolaCastro \& Ohman, 2006). Furthermore, in some tropical areas the salp community composition can change over time, with species appearing and disappearing, without changes in water masses (Madin et al., 1996).

Although this study was carried out over only one year, it is probable that the fluctuations observed in tunicate numbers occur in 
roughly the same pattern every year, since the oceanographic and climatic influences that favor tunicate increases occur in the same fashion every year. Seasonal patterns in the occurrence of abundance peaks of salps have also been observed in other areas (Ménard et al., 1994; Licandro, Ibañez \& Etienne, 2006; Deibel \& Paffenhöfer, 2009). Tunicates could be a seasonal food resource for sea turtles and other filter-feeding vertebrates if their abundance is directly linked to recurring oceanographic patterns.

According to Worm, Lotze \& Myers (2003), biodiversity hotspots are places of high food concentration resulting from oceanographic processes that increase productivity. Morales-Ramírez (2008) also noted that there is higher plankton productivity around oceanic islands than in the open ocean. Around Gorgona Island large predators such as sharks, whales and manta rays can be observed as well as sea turtles (Barrios-Suárez \& López-Victoria, 2001; Acevedo-Bueno et al., 2004); therefore, Gorgona Island might be a place of high food concentration that sea turtles benefit from, explaining the fact that green sea turtle juveniles use the area as a feeding ground.

\section{ACKNOWLEDGMENTS}

We thank Bellineth Valencia for help in tunicate identification. This paper is part of the L.S.'s doctoral research, which was partly financed by the Natural Sciences and Engineering Research Council of Canada (NSERC) through a PGSD award, and by the Postgraduate Biology Program of the Universidad del Valle through a Teaching Assistantship. Zooplankton samples were collected under research permit DTSO 035/2005 of UAESPNN granted to A.G.

\section{RESUMEN}

Se determinó la abundancia de salpas y doliólidos en ocho estaciones costeras alrededor de Isla Gorgona (Pacífico colombiano), entre septiembre 2005 y agosto 2006. Se hicieron arrastres oblicuos desde $50 \mathrm{~m}$ hasta la superficie; se midió la biomasa zooplanctónica total, el número de salpas y doliólidos por arrastres, y la frecuencia de ocurrencia por estación y por mes. Se registró la temperatura superficial y de fondo, la salinidad superficial y de fondo, así como la concentración de clorofila $a$ en cada estación. Se observaron picos de abundancia de tunicados en septiembre 2005 y marzo 2006. Las altas abundancias en marzo fueron probablemente debidas a una intrusión de agua fría a la zona de estudio, la cual resultó en aguas más frías y saladas, y en una termoclina más somera. Los tunicados fueron probablemente advectados hacia el área por corrientes provenientes del suroeste, y la topografía subacuática causó una agregación de estos organismos. En septiembre, la influencia de las descargas de los ríos continentales, así como aportes por la precipitación sobre la isla pudieron haber provisto mayor cantidad de nutrientes y resultado en mayores abundancias. Los grandes vertebrados marinos filtradores que se alimentan de tunicados incluyen tortugas verdes juveniles, las cuales usan las aguas de Isla Gorgona como zona de forrajeo, como parte de su ruta de migración en el Pacífico Oriental Tropical. Estas tortugas podrían estar utilizando los tunicados oportunistamente, como un recurso esporádico que está disponible en ciertas épocas del año.

Palabras clave: Chelonia mydas, tunicados, Salpidae, Doliolidae, Isla Gorgona, comportamiento trófico oportunista, advección.

\section{REFERENCES}

Acero, A. \& Franke, R. (2001). Peces del parque nacional natural Gorgona. In L. M. Barrios \& M. LopézVictoria (Eds.), Gorgona marina: Contribución al conocimiento de una isla única (pp. 123-131). Serie Publicaciones Especiales No 7, Instituto Investigaciones Marinas y Costeras-INVEMAR. Santa Marta, Colombia.

Acevedo-Bueno, C. I., Beltrán-León, B. S. \& CaicedoTulante, R. A. (2004). Plan básico de manejo 20052009. Parque Nacional Natural Gorgona. Parques Nacionales Naturales de Colombia. Dirección Territorial Suroccidente. Cali, Colombia.

Alldredge, A. L. \& Madin, L. P. (1982). Pelagic tunicates: unique herbivores in the marine plankton. BioScience, 32: 655-663.

Alvarado, J. \& Figueroa, A. (1992). Recapturas post-anidatorias de hembras de tortuga marina negra (Chelonia agassizii) marcadas en Michoacán, México. Biotropica, 24: 560-566.

Amorocho, D. F. \& Reina, R. D. (2007). Feeding ecology of the East Pacific green sea turtle Chelonia mydas agassizii at Gorgona National Park, Colombia. Endangered Species Research, 3: 43-51. 
Amorocho, D. F. \& Reina, R. D. (2008). Intake passage time, digesta composition and digestibility in East Pacific green turtles (Chelonia mydas agassizii) at Gorgona National Park, Colombian Pacific. Journal of Experimental Marine Biology and Ecology, 360: 117-124.

Arthur, K. E. \& Balazs, G. H. (2008). A comparison of immature green turtle (Chelonia mydas) diets among seven sites in the main Hawaiian Islands. Pacific Science, 62: 205-217.

Barrios, L. M. \& López-Victoria, M. (2001). (Eds). Gorgona marina: Contribución al conocimiento de una isla única, Serie Publicaciones Especiales No 7, Instituto Investigaciones Marinas y Costeras-INVEMAR. Santa Marta, Colombia.

Bjorndal, K. A. (1985). Nutritional ecology of sea turtles. Copeia, 3: 736-751.

Blanco, J. F. (2009). The hydroclimatology of Gorgona Island: Seasonal and ENSO-related patterns. Actualidades Biológicas, 31: 111-121.

Bula-Meyer, G. (1995). Macroalgas de la Isla Gorgona (Pacífico Colombiano) con nuevos registros y una explicación de la baja diversidad y biomasa. In P. Pinto (Ed.), La Isla Gorgona, nuevos estudios biológicos, (pp. 23-45). Editorial Guadalupe LTDA, Bogotá, Colombia.

Carrión-Cortez, J. A., Zárate, P. \& Seminoff, J. A. (2010). Feeding ecology of the green sea turtle (Chelonia mydas) in the Galapagos Islands. Journal of the Marine Biological Association of the United Kingdom, 90:1005-1013.

Deibel, D. \& Paffenhöfer, G. A. (2009). Predictability of patches of neritic salps and doliolids (Tunicata, Thaliacea). Journal of Plankton Research, 31: 1571-1579.

Dewar, H., Thys, T., Teo, S. L. H., Farwell, C., O'Sullivan, J., Tobayama, T., Soichi, M., Naktasubo, T., Kondo, Y., Okada, Y., Lindsay, D. J., Hays, G. C., Walli, A., Weng, K., Streelman, J. T. \& Karl, S. A. (2010). Satellite tracking the world's largest jelly predator, the ocean sunfish, Mola mola, in the Western Pacific. Journal of Experimental Marine Biology and Ecology, 393: 32-42.

Fernández-García, C., Riosmena-Rodríguez, R., Wysor, B., Tejada, O. L., \& Cortés, J. (2011). Checklist of the Pacific marine macroalgae of Central America. Botánica Marina, 54: 53-73.

Frontier, S. (1969). Sur une méthode d'analyse faunistique rapide du zooplancton. Journal of Experimental Marine Biology and Ecology, 3: 18-26.

Genin, A., Jaffe, J. S., Reef, R., Richter, C. \& Franks, P. J. S. (2004). Swimming against the flow: A mechanism of zooplankton aggregation. Science, 308: 860-862.
Giraldo, A. 2008. Variabilidad espacial de temperatura, salinidad y transparencia en el ambiente pelágico del PNN Gorgona durante septiembre 2007 y marzo 2008. Boletín Cientifico. Centro de Investigaciones Oceanográficas e Hidrográficas del Caribe, 26: 157-163.

Giraldo, A., Rodríguez-Rubio, E. \& Zapata, F. (2008). Condiciones oceanográficas en isla Gorgona, Pacífica oriental tropical de Colombia. Latin American Journal of Aquatic Research, 36: 121-128.

Giraldo, A., Valencia, B. \& Ramírez, D. G. (2011). Productividad planctónica y condiciones oceanográficas locales en isla Gorgona durante julio 2006. Boletín de Investigaciones Marinas y Costeras, 40: 185-201.

Giraldo, A. \& Valencia, B. (2012). (Eds.). Isla Gorgona. Paraíso de biodiversidad y ciencia (pp. 223). Programa Editorial Universidad del Valle. Cali, Colombia.

Giraldo, A., Valencia, B., Acevedo, J. D. \& Rivera, M. (2013). Variación estacional del fitoplancton y zooplancton en Isla Gorgona, Pacífico Colombiano, y su relación con algunas variables hidrográficas. Revista de Biología Tropical, Vol. 62 (Supl. 1) 117-132.

Graham, W. M., Pagès, F. \& Hamner, W. M. (2001). A physical context for gelatinous zooplankton aggregations: a review. Hydrobiología, 451: 199-212.

Hays, G. C., Farquhar, M. R., Luschi, P., Teo S. L. H. \& Thys, T.M. (2009). Vertical niche overlap by two ocean giants with similar diets: Ocean sunfish and leatherback turtles. Journal of Experimental Marine Biology and Ecology, 370: 134-143.

Hereu, C. M., Lavaniegos, B. E., Gaxiola-Castro, G. \& Ohman, M. D. (2006). Composition and potential grazing impact of salp assemblages off Baja California during the 1997-1999 El Niño and La Niña. Marine Ecology Progress Series, 318: 123-140.

Kremer, P. (2002). Towards an understanding of salp swarm dynamics. ICES publication CM2002. N: 12. Copenhagen, Denmark.

Lavaniegos, B. E. \& Ohman, M. D. (2003). Long-term changes in pelagic tunicates of the California Current. Deep-Sea Research Part II, 50: 2473-2498.

Licandro, P., Ibañez, F. \& Etienne, M. (2006). Long-term fluctuations (1974-1999) of the salps Thalia democratica and Salpa fusiformis in the northwestern Mediterranean Sea: Relationships with hydroclimatic variability. Association for the Sciences of Limnology and Oceanography, 51: 1832-1848.

López-Mendilaharsu, M., Gardner, S. C., Riosmena-Rodríguez, R. \& Seminoff, J.A. (2008). Diet selection by immature green turtles (Chelonia mydas) at Bahía Magdalena foraging ground in the Pacific Coast of the Baja California Peninsula, México. Journal of the Marine Biological Association of the United Kingdom, 88: 641-647. 
Madin, L. P, Kremer, P. \& Hacker, S. (1996). Distribution and vertical migration of salps (Tunicata, Thaliacea) near Bermuda. Journal of Plankton Research, 18: 747-755.

Ménard, F., Dallot, S., Thomas, G. \& Braconnot, J. C. (1994). Temporal fluctuations of two Mediterranean salp populations from 1967 to 1990 . Analysis of the influence of environmental variables using a Markov chain model. Marine Ecology Progress Series, 104: 139-152.

Montenegro-Silva, B. C., Bernal-González, N. G. \& Martínez-Guerrero, A. (1984). Estudio del contenido estomacal de la tortuga marina Lepidochelys olivacea, en la costa de Oaxaca, México. Anales del Instituto de Ciencias del Mar y Limnología, 13:121-32.

Morales-Ramírez, A. (2008). Caracterización cualitativa del zooplancton del Área de Conservación Marina Isla del Coco (ACMIC), Océano Pacífico de Costa Rica. Revista de Biología Tropical, 56: 159-169.

Pagès, F. \& Gili, J. M. (1991). Effects of large-scale advective processes on gelatinous zooplankton populations in the northern Benguela ecosystem. Marine Ecology Progress Series, 75: 205-215.

Potter, I. F., Galuardi, B. \&, Howell, W. H. (2011). Horizontal movement of the ocean sunfish, Mola mola, in the northwest Atlantic. Marine Biology, 158: $531-540$.

Rodríguez-Rubio, E., Schneider, W. \& Abarca del Río, R. (2003). On the seasonal circulation within the Panama Bight derived from satellite observations of wind, altimetry and sea surface temperature. Geophysical Research Letters, 30: 1410-1413.

Soto, P. A., Sánchez, S. L. \& Fernández, C. (2001). Comunidades planctónicas marinas. In L. M. Barrios \& M. L. Victoria (Eds.), Gorgona Marina: Contribución al conocimiento de una isla única (pp. 93-105). Serie Publicaciones Especiales No 7, Instituto Investigaciones Marinas y Costeras-INVEMAR. Santa Marta, Colombia.

Worm, B., Lotze, H. K. \& Myers, R. A. (2003). Predator diversity hotspots in the blue ocean. Proceedings of the National Academy of Sciences, 100: 9884-9888.

Zapata, F. A. (2001). Ecología de peces arrecifales en Gorgona: composición, abundancia, diversidad e historia de vida temprana. In L.M. Barrios \& M. LópezVictoria (Eds,). Gorgona marina: Contribución al conocimiento de una isla única (pp. 111-122). Serie Publicaciones Especiales No 7, Instituto Investigaciones Marinas y Costeras-INVEMAR, Santa Marta, Colombia.

Zapata, F. A., Rodríguez-Ramírez, A., Caro-Zambrano, C. \& Garzón-Ferreira, J. (2010). Mid-term coral-algal dynamics and conservation status of a Gorgona Island (Tropical Eastern Pacific) coral reef. Revista de Biología Tropical, 58: 81-94.

Zug, G. R., Balazs, G. H., Wetherall, J. A., Parker, D. M. \& Murakawa, S. K. K. (2002). Age and growth of Hawaiian green seaturtles (Chelonia mydas): an analysis based on skeletochronology. Fishery Bulletin, 100: 117-127. 
